\title{
International Evidence on the Determinants of Private Saving
}

\author{
Paul R. Masson, Tamim Bayoumi, and Hossein Samiei
}

\begin{abstract}
A broad set of possible determinants of private saving behavior is examined using data for a large sample of industrial and developing countries. Both time-series and crosssectional estimates are obtained. Results suggest that there is a partial offset on private saving of changes in public saving and (for developing countries) in foreign saving, that demographics and growth are important determinants of private saving rates, and that interest rates and terms of trade have positive, but less robust, effects. Increases in per capita gross domestic product seem to increase saving at low income levels (relative to the United States) but decrease it at higher ones.
\end{abstract}

Despite an extensive literature on saving behavior, several empirical issues have not been resolved conclusively, including the effects of real interest rates, demographic factors, and per capita income on private saving; the relationship between growth and saving; and the extent to which private saving offsets movements in public (dis)saving (Aghevli and others 1990 and Deaton 1992). This article extends the empirical knowledge of private saving behavior by exploiting data for a large sample of industrial and developing countries and by looking at a broad set of possible determinants of private saving. It uses both time-series and cross-sectional information because the variability of potential explanatory variables differs in those two dimensions. In particular, some variables seem to explain persistent country differences (for example, dependency ratios or relative per capita income), while others are correlated with year-to-year fluctuations (for example, the terms of trade or growth in gross domestic productGDP). Fiscal variables seem to explain both some persistent long-term differences and short-term fluctuations.

The existing literature tends to be limited to one of these two dimensions, one of the few exceptions being Schmidt-Hebbel, Webb, and Corsetti (1992), who use panel data to study behavior across developing countries. ${ }^{1}$ Conclusions con-

1. After the first version of this article was drafted, we discovered a study by Edwards (1996), covering related issues and coming to similar conclusions, but with a somewhat different empirical and policy emphasis.

Paul R. Masson, Tamim Bayoumi, and Hossein Samiei are with the Research, Asia and Pacific, and European I departments, respectively, at the International Monetary Fund. The authors are grateful to colleagues and seminar participants at the World Bank, to Klaus Schmidt-Hebbel and to David Weil for advice and comments, and to Toh Kuan and particularly to Claire Adams for data and computing assistance.

- 1998 The International Bank for Reconstruction and Development / THE WORLD BANK 
cerning the significance of one or another factor have often depended importantly on the choice of time-series or cross-sectional estimation, as well as the country or countries included. For instance, time-series estimation has typically found evidence of demographic effects on private saving in Japan but not in the United States, whereas cross-sectional estimates have yielded large effects (see Horioka 1993 on Japan, Carroll and Summers 1991 on the United States, and Modigliani 1970 and Graham 1987 for cross-sectional estimates). By exploiting both dimensions and using data for 61 industrial and developing countries, we examine the robustness of more limited studies.

\section{OUTSTANDING EMPIRICAL ISSUES}

This section provides a selective survey of unresolved issues.

\section{Does Private Sector Saving Offset Government Dissaving?}

The empirical literature on the private saving offset to government deficits (or dissaving) has generally concluded that a full offset (Ricardian equivalence) is rejected by the data, with some dissenters. According to Bernheim (1987), existing evidence for industrial countries indicates that a unit increase in the government deficit would be associated with a decrease in consumption of 0.5 to 0.6 . He presents new empirical results tending to confirm this range. Others have obtained similar results for developing countries. Corbo and Schmidt-Hebbel (1991), in a typical estimate, find a roughly 50 percent offset on private saving of changes in government saving. Haque and Montiel (1989) overwhelmingly reject Ricardian equivalence for their sample of 16 developing countries. They also conclude that the presence of liquidity constraints affecting at least some households causes the nonequivalence. Hayashi (1985), Flavin (1981), and Campbell and Mankiw (1989) find evidence that households in industrial countries face liquidity constraints. By contrast, Seater (1993) argues that much of the empirical work is inadequate and concludes that the evidence supports the hypothesis of Ricardian equivalence. Nevertheless, he recognizes that different government behavior than in the past could imply Ricardian nonequivalence in the future.

An increase in the government deficit as a result of lower taxes or higher government spending can have different effects on private saving, so the estimation in section II allows these variables to have separate coefficients. Increased government spending may lower the resources available to the private sector and hence have a negative effect on private saving, regardless of whether it affects the deficit. The composition of government spending may also be important. Public investment, to the extent that it is viewed as productive, is not expected to require further taxes and should not generate a private saving response. Its coefficient in a saving equation should be smaller than the coefficient of government consumption. In contrast, investment that does not gener- 
ate revenues for the government (and is considered equivalent to government consumption) would involve future taxes and might induce a larger private saving offset.

\section{Does Income Growth Raise Saving?}

Modigliani (1966) argues that a higher growth rate (whether due to population or productivity growth) would, with unchanged saving rates by age group, raise aggregate saving because it would increase the aggregate income of those working relative to those not earning labor income (that is, retired persons living off their accumulated assets). This view is based on the life-cycle hypothesis, which relates saving behavior to successive stages of schooling, increased earnings, and retirement (Modigliani and Brumberg 1954 and Modigliani and Ando 1957). In fact, saving does seem to be positively correlated with income growth, because high-growth countries such as Japan or Korea also have high saving rates (Modigliani 1970).

However, Tobin (1967) points out that unchanged individual saving rates are only consistent in this context with myopic expectations of future income. If workers correctly expect that their income will grow in the future, according to the life-cycle model, they should want to consume more today. Thus, saving rates for working individuals could fall by a sufficient amount to offset the aggregate effects of higher growth, a hypothesis confirmed by back-of-theenvelope calculations given the length of working lives relative to retirement. Thus the empirical positive correlation of saving with income growth is not, on the face of it, consistent with the life-cycle hypothesis, unless the higher income growth is at least partly transitory.

Carroll and Weil (1994) confirm that lagged values of increases in income growth seem to explain higher saving rates; they argue that the usual consumption models with either uncertainty or liquidity constraints are not sufficient to explain this result and advance instead the hypothesis of habit persistence, according to which higher consumption associated with temporarily higher income takes some time to be reduced when income falls back. If growth leads to higher saving, for whatever reason, then these are important implications for countries like Japan whose growth has slowed. However, another explanation for the correlation may be that a high growth rate is a proxy for a high rate of return on capital, which may be reflected inadequately in domestic interest rates (especially if financial markets are not liberalized).

\section{Do Higher Interest Rates Lead to Higher Saving?}

The effect of interest rates on consumption is ambiguous theoretically, being subject to potentially offsetting negative substitution and positive income effects, the latter reflecting the fact that the private sector is a net creditor in financial assets. It is true that human wealth (that is, discounted future labor income) is much larger than financial wealth for a typical individual and that human 
wealth varies inversely with the rate of interest-suggesting that the negative substitution effect should dominate. However, consumers may not plan their lifetime consumption but instead respond primarily to current income. The saving behavior of pension plans enhances the empirical importance of the income effect on private saving. For defined benefit plans, higher interest rates increase the income available to pay pensions, allowing lower contributions (Bernheim and Shoven 1988). Empirical research has reported mixed results, paralleling the theoretical ambiguity. For instance, using data on saving for industrial countries, Bosworth (1993) finds a positive interest rate coefficient in a time-series estimation for individual countries, but a negative coefficient in a panel (crosscountry) estimation. For developing countries, Giovannini (1985) concludes that in most cases the real interest elasticity is zero, while Schmidt-Hebbel, Webb, and Corsetti (1992) also find no clear effects on saving. Ogaki, Ostry, and Reinhart (1995) find positive interest rate effects that vary with income but are still small.

Given that financial liberalization may have changed the interest rate effects, it is not too surprising that results are not robust. The effect of liberalization on saving behavior can operate through at least two channels. First, financial development may provide outlets for financial saving, thereby raising saving rates, a channel that has been emphasized in the development literature (McKinnon 1973 and Shaw 1973). However, although financial liberalization generally affects the form that saving takes and also the efficiency of investment, it need not raise the level of saving (De Gregorio and Guidotti 1994). The second aspect involves the liberalization of consumer access to bank credit, as occurred in a number of industrial countries in the 1980s. Regulatory changes have allowed banks to lend more freely to individuals, for instance for purchase of a house or for consumption, and this may lead, at least initially, to a significant decline in saving. Empirical evidence supports this effect in countries that have liberalized access to consumer credit (Jappelli and Pagano 1989, Bayoumi 1993, Lehmussaari 1990, and Ostry and Levy 1995). Financial liberalization may involve one or another of these aspects, each of which will tend to increase the sensitivity of saving to interest rates. Financial liberalization in a given country may also expand the international diversification possibilities of other countries, making their saving more responsive to foreign interest rates.

\section{Does Saving Vary with a Country's Income Level?}

Differences in per capita income could be one of the factors that explain the wide range of saving rates in developing countries. At subsistence levels, the potential for significant saving is small. A rise in per capita income may therefore lead to higher saving rates. The size of this effect is likely to decline as per capita income rises and may even become negative for rich countries where investment opportunities and growth are relatively lower. It seems to be a stylized fact that the process of development involves initially low saving rates, a period of high growth accompanied by high saving rates, and 
lower saving rates in more mature economies (see Ogaki, Ostry, and Reinhart 1995).

\section{Is the Age Structure a Significant Influence on Saving?}

The life-cycle hypothesis highlights the importance of the age structure of the population. If a high proportion of the population is of working age-especially if at peak earning years-then the economy should have a high rate of private saving, as workers provide for their retirement. Conversely, when this cohort reaches retirement age and dissaves (or, at least, consumes a greater fraction of its income), then the aggregate saving rate should decline. An extensive literature attempts to link demographic variables to saving behavior. Studies using cross-country data (either as cross sections or as panels) have been more successful than time-series studies for individual countries in finding significant demographic effects, probably because the variation over time of demographic variables is relatively small. In particular, Leff (1969), Modigliani (1970), Modigliani and Sterling (1983), Graham (1987), and Masson and Tryon (1990) find that higher proportions of the young and elderly in relation to persons of working age-dependency ratios-are associated with lower saving rates. These estimates, and the projections of population aging in coming decades, would produce quite large falls in private saving in many industrial countries, especially in Japan.

Koskela and Viren (1989) question the robustness of the cross-country demographic effects identified by Graham (1987). And macroeconomic results (including across countries) conflict with studies using micro data for consumers by age cohort. Kennickell (1990) and Carroll and Summers (1991), for instance, argue that age-consumption profiles do not differ enough to explain why aggregate consumption should be very much affected by demographic factors. The discrepancy may be explained, however, by interactions between generations that are picked up by the macro data but ignored by the micro data studies: bequests may lower the saving of the young, and hence aggregate saving, even if the elderly do not themselves dissave (Weil 1994). Therefore, the thought experiment of changing the age structure of the population while keeping agespecific saving profiles unchanged may not be legitimate. Nevertheless, it must be acknowledged that studies using macro data have also found diverse results.

\section{Is There a Terms-of-Trade Effect on Saving?}

Another aspect of saving behavior that has appeared in the literature is the possible relationship between the terms of trade and saving (the HarbergerLaursen-Metzler effect). That is, an improvement in the terms of trade leads to an increase in saving and an improvement in the trade balance. The modern literature integrates this effect into intertemporal models and stresses the distinction between transitory and permanent changes in the terms of trade. A transitory improvement, because it causes only a transitory change in income, should lead to higher saving rather than higher consumption, confirming the direction of the Harberger-Laursen-Metzler effect (Obstfeld 1982 and Svensson and Razin 
1983). Permanent shocks to the terms of trade would have ambiguous effects that should be small in magnitude. The empirical literature tends to confirm a positive correlation between transitory terms-of-trade shocks and saving (Ostry and Reinhart 1992).

\section{Other Potential Determinants}

Other possible explanatory factors include inflation, wealth, and foreign saving. Inflation may affect saving for several reasons: higher irflation tends to lead to higher nominal interest rates and hence higher measured household income and saving. However, higher inflation may also lower saving by increasing uncertainty. Financial wealth should negatively affect saving in a life-cycle model, because it increases the resources available for consumption. Foreign saving becomes a potential exogenous determinant of national saving when foreign borrowing is rationed, as often is the case in developing countries. Some empirical evidence supports such a negative relationship between national and foreign saving (Fry 1978, 1980 and Giovannini 1985) and between household and foreign saving (Schmidt-Hebbel, Webb, and Corsetti 1992).

\section{EMPIRICAL RESULTS}

We regressed saving rates for industrial and developing countries on several potential explanatory variables that could be collected on a reasonably comparable basis across all countries. For the industrial countries, the panel data set contains 21 countries over 1971-93. It contains 23 industrial countries, as defined by the International Monetary Fund, excluding Iceland and Luxembourg. See the appendix for data sources. ${ }^{2}$ Measurement issues are discussed by Blades and Sturm (1982), Lipsey and Kravis (1987), and Elmeskov, Shafer, and Tease (1991).

In addition to the ratio of private saving to GDP, the data set consists of the general government budget surplus, government current expenditure, government investment, and beginning-of-period private sector wealth (all measured as ratios of nominal GDP); growth rates of real output, consumer prices, and the terms of trade; the real short-term interest rate; GDP per capita relative to that in the United States (measured using purchasing power parities); and the dependency ratio (the ratio of persons under 20 and over 64 to persons ages 20-64). Separating the overall dependency ratio into dependency ratios for the young and the old gave coefficients that were not significantly different from each other. The private wealth variable includes the stock of government debt. To the extent that individuals are Ricardian, however, this debt should not be included in private wealth. Results when the stock of government debt was included in the specification as a separate variable were very similar to the main case and are not reported.

2. The data are available from the authors, either on a diskette or by e-mail (pmasson@imf.org). 
We collected the same variables for a sample of 40 developing countries over 1982-93. Several variables in the developing-country data had to be constructed due to limitations of the data. We calculated national saving as domestic investment plus the current account surplus, which means that foreign transfers are included as part of national saving. We calculated private saving as national saving minus the central government fiscal surplus and minus central government expenditure on capital goods. Hence, private saving includes saving by lower levels of government. In addition, we derived private wealth as the cumulative sum of nominal private savings. Because most developing countries face constraints on their external borrowing, foreign saving is also likely to be a determinant of domestic saving. Therefore, we included the current account surplus (equal to minus foreign saving) as a determinant of saving in the case of developing countries. Because the current account includes net private and official transfers, it excludes foreign aid from foreign saving. Data on foreign aid were not available on a balance of payments basis. Thus the estimations reported here did not test for the effect of foreign aid on national saving.

Panel data provide variation both across countries and over time. Table 1 provides information on some of the characteristics of the underlying data. It divides the total variance of each of the series into the part ascribed to changes over time within countries (the time-series variation) and the part ascribed to long-term differences across countries (the cross-sectional variation). Briefly, the variation over time was calculated by summing the individual variances across countries assuming that each country has a different mean. The cross-sectional variation was calculated as the variance across these country means multiplied

Table 1. Cross-Sectional and Time-Series Variance in the Variables for Industrial and Developing Countries

(percentage of total variance)

\begin{tabular}{|c|c|c|c|c|}
\hline \multirow[b]{2}{*}{ Variable } & \multicolumn{2}{|c|}{ Industrial countries } & \multicolumn{2}{|c|}{ Developing countries } \\
\hline & $\begin{array}{c}\text { Across } \\
\text { countries }\end{array}$ & $\begin{array}{l}\text { Over } \\
\text { time }\end{array}$ & $\begin{array}{c}\text { Across } \\
\text { countries }\end{array}$ & $\begin{array}{l}\text { Over } \\
\text { time }\end{array}$ \\
\hline Private saving/GDP & 65.6 & 34.4 & 77.2 & 22.8 \\
\hline Government budget surplus/GDP & 60.5 & 39.5 & 53.6 & 46.4 \\
\hline Government current expenditure/GDP & 67.3 & 32.7 & 90.5 & 9.5 \\
\hline Government investment/GDP & 62.1 & 37.9 & 72.5 & 27.5 \\
\hline GDP growth rate & 8.2 & 91.8 & 20.7 & 79.3 \\
\hline Real interest rate & 13.2 & 86.8 & 36.7 & 63.3 \\
\hline Wealth/GDP & 66.7 & 33.3 & 82.1 & 17.9 \\
\hline Inflation rate & 24.5 & 75.5 & 67.5 & 32.5 \\
\hline Percent change in terms of trade & 1.1 & 98.9 & 4.4 & 95.6 \\
\hline Per capita GDP relative to the United States & 94.7 & 5.3 & 97.0 & 3.0 \\
\hline Dependency ratio & 62.3 & 37.7 & 95.7 & 4.3 \\
\hline Current account/GDP & - & - & 35.7 & 64.3 \\
\hline
\end{tabular}

- Not available.

Note: The analysis uses 1971-93 data for 21 industrial countries and 1982-93 data for 40 developing countries. See the appendix for countries, variable definitions, and data sources.

Source: Authors' calculations. 
by the number of time periods. The two measures sum to the total variation. Note that the greater number of observations for industrial countries implies that a larger proportion of the total variance for these countries is accounted for by variance over time. See Kessler, Perelman, and Pestieau (1993) for a more detailed description of this approach.

From table 1, private saving, the dependent variable, contains significant amounts of variation in both dimensions across both data sets, with crosssectional differences explaining 60-80 percent of the total variance and changes over time explaining the remainder. The importance of the cross-sectional differences presumably reflects the persistence of differences in saving behavior across countries. For example, countries such as China, Italy, Japan, and Korea had relatively high private saving ratios throughout the sample period, while Kenya, the United Kingdom, the United States, and Uruguay had relatively low ratios.

Cross-sectional differences are also more important than changes over time for the fiscal variables, the dependency ratio, the wealth ratio, and per capita GDP relative to the United States. By contrast, most of the variation in real short-term interest rates, output growth, the change in the terms of trade, and the current account is across time, presumably reflecting the greater importance of cyclical variation in these cases. Inflation in industrial countries also shows more variation over time, but in developing countries the reverse is true. Most variables have significant variation across both countries and time, indicating that useful information can be extracted in both dimensions, the main exceptions being relative per capita GDP and the change in the terms of trade. The panel regressions focus on four principal explanatory factors as determinants of private saving: fiscal variables; demographics; GDP per capita and GDP growth; and interest rates, inflation, and changes in the terms of trade.

\section{A Combined Panel of Industrial and Developing Countries}

We combined the industrial- and developing-country data sets to produce an unbalanced panel involving a total of 61 countries: 21 industrial countries with 23 years of data (1971-93) and 40 developing countries with 12 years of data (1982-93). The data were treated identically across all countries except for the current account, which was eliminated from the estimation for industrial countries.

In order to allow for different intercepts for each of the countries, "fixed effects" estimation was performed by including separate country dummies in the initial ordinary least squares (oLs) regressions. These coefficients (or rather $n-1$ of them) were always jointly significant. We included time dummies for each year to account for the possible common effect of excluded variables on all countries' saving rates. However, the estimates for the other coefficients were not affected in a substantial way, so that only the estimates without time dummies are reported here. 
The first column in table 2 reports the results from a general specification including all the variables, estimated using ols with country dummies. The coefficients generally have signs that accord with intuition and are significant. Increases in the general government budget surplus (the fiscal position), government current and capital expenditure, and the dependency ratio all lower private saving, while increases in the GDP growth rate and wealth raise it.

Table 2. Determinants of Private Saving: Results from the Combined Industrial- and Developing-Country Panel

\begin{tabular}{|c|c|c|c|}
\hline Variable & $\begin{array}{c}\text { Ordinary } \\
\text { least } \\
\text { squares }\end{array}$ & $\begin{array}{c}\text { Corrected } \\
\text { for serial } \\
\text { correlation, }\end{array}$ & $\begin{array}{c}\text { First-difference, } \\
\text { instrumental } \\
\text { variables }\end{array}$ \\
\hline Government budget surplus/GDP & $\begin{array}{r}-0.60 \\
(13.1)\end{array}$ & $\begin{array}{r}-0.75 \\
(19.9)\end{array}$ & $\begin{array}{r}-0.81 \\
(10.1)\end{array}$ \\
\hline Government current expenditure/GDP & $\begin{array}{r}-0.32 \\
(10.2)\end{array}$ & $\begin{array}{c}-0.27 \\
(7.2)\end{array}$ & $\begin{array}{c}-0.14 \\
(2.2)\end{array}$ \\
\hline Government investment/GDP & $\begin{array}{r}-0.24 \\
(3.8)\end{array}$ & $\begin{array}{c}-0.35 \\
(5.9)\end{array}$ & $\begin{array}{l}-0.42 \\
(6.5)\end{array}$ \\
\hline GDP growth rate & $\begin{array}{c}0.11 \\
(3.5)\end{array}$ & $\begin{array}{l}0.092 \\
(4.1)\end{array}$ & $\begin{array}{r}0.22 \\
(1.5)\end{array}$ \\
\hline Real interest rate & $\begin{array}{r}0.03 \\
(1.1)\end{array}$ & $\begin{array}{l}-0.026 \\
\langle 1.1\rangle\end{array}$ & $\begin{array}{r}0.10 \\
(0.6)\end{array}$ \\
\hline Wealth/GDP & $\begin{array}{l}0.012 \\
(3.0)\end{array}$ & $\begin{array}{l}-0.0038 \\
(0.7)\end{array}$ & $\begin{array}{l}-0.016 \\
(1.3)\end{array}$ \\
\hline Inflation rate & $\begin{array}{l}0.003 \\
(0.1)\end{array}$ & $\begin{array}{l}-0.042 \\
(1.9)\end{array}$ & $\begin{array}{l}0.089 \\
(0.6)\end{array}$ \\
\hline Percent change in the terms of trade & $\begin{array}{l}0.011 \\
(1.3)\end{array}$ & $\begin{array}{l}0.0098 \\
(1.9)\end{array}$ & $\begin{array}{l}0.005 \\
(0.8)\end{array}$ \\
\hline Per capita GDP relative to U.S. & $\begin{array}{r}0.51 \\
(4.6)\end{array}$ & $\begin{array}{r}0.53 \\
(3.8)\end{array}$ & $\begin{array}{l}0.076 \\
(0.2)\end{array}$ \\
\hline Per capita GDP relative to U.S. squared & $\begin{array}{l}-0.004 \\
(4.7)\end{array}$ & $\begin{array}{l}-0.0039 \\
(3.6)\end{array}$ & $\begin{array}{l}-0.001 \\
(0.5)\end{array}$ \\
\hline Current account/GDP & $\begin{array}{r}0.44 \\
(12.4)\end{array}$ & $\begin{array}{r}0.53 \\
(16.9)\end{array}$ & $\begin{array}{r}0.71 \\
(4.0)\end{array}$ \\
\hline Dependency ratio & $\begin{array}{c}-0.14 \\
(6.7)\end{array}$ & $\begin{array}{r}-0.13 \\
(4.2)\end{array}$ & $\begin{array}{c}-0.14 \\
(1.6)\end{array}$ \\
\hline Fit statistics & & & \\
\hline Adjusted $R^{2}$ & 0.89 & 0.69 & 0.43 \\
\hline Standard error of regression & 2.99 & 2.27 & 2.24 \\
\hline $\begin{array}{l}\text { Durbin-Watson } \\
\text { Panel autocorrelation coefficient, } \rho\end{array}$ & 0.90 & $\begin{array}{l}1.91 \\
0.64\end{array}$ & 1.85 \\
\hline Number of observations & 963 & 963 & 780 \\
\hline
\end{tabular}

Note: The dependent variable is the private saving/GDP ratio. Regressions are estimated using 197193 data for 21 industrial countries and 1982-93 data for 40 developing countries. Absolute $t$-ratios are in parentheses. See the appendix for countries, variable definitions, and data sources.

a. Country dummies were included, but their coefficients are not reported.

b. Dependent and independent variables are quasi-differenced to eliminate residual serial correlation, using the method of Bhargava, Franzini, and Narendranathan (1982).

c. Developing countries only.

Source: Authors' calculations. 
The results also support the hypothesis of a quadratic relationship between the national saving rate and per capita income. The estimated coefficients suggest that the turnaround is mild and occurs at around 60 percent of U.S. per capita income. We included the current account ratio only for developing countries to measure the availability of financing. It has a strong positive effect on private saving. Finally, the coefficients on inflation, the real interest rate, and the percent change in the terms of trade are small and insignificant.

However, a problem with the oLs results is the presence of serial correlation of the residuals, as evidenced by the low Durbin-Watson statistic calculated across the panel. (See Bhargava, Franzini, and Narendranathan 1982 for a generalization of the usual time-series statistics to panel data.) In order to avoid biasing estimates of standard errors, a small-sample estimate of the panel autocorrelation coefficient $(\rho)$ was then calculated iteratively, using the formula in Bhargava, Franzini, and Narendranathan (1982), and the original series for the dependent and independent variables were then quasi-differenced. In particular, each observation $X_{t}$ was replaced by $X_{t}-\rho X_{t-1}$, except for the first observation, which was multiplied by $\sqrt{1-\rho^{2}}$. The regression results reported in the second column in table 2 are based on the quasi-differenced series.

In many respects, the estimates resulting from a serial correlation correction confirm the oL $S$ results, with a few notable exceptions. The fiscal variables are all still significant, but a change in the government budget surplus now produces a larger offset from private saving, about three-quarters. The GDP growth rate has a strong positive effect on private saving, the dependency ratio has a negative effect, and the same quadratic relationship between per capita income and saving emerges. The current account ratio has an even stronger and more significant effect for developing countries. The coefficient of the terms of trade continues to be (barely) insignificant, as does that for the inflation rate, which, however, changes sign, and the coefficient for the wealth variable is now insignificant.

A further potential problem with these results is that saving may be determined simultaneously with some of the other variables, in particular GDP growth, the real interest rate, and developing countries' current account ratios, causing the estimated coefficients to be biased. Accordingly, we reestimated the model after using first differencing and using as instrumental variables only the second lags of the above variables plus the other explanatory variables. (For the use of first differencing in the more general context of dynamic panel models, see, for example, Anderson and Hsiao 1982.) First differencing removes fixed effects and hence does not require the inclusion of country dummies (or de-meaning). It also allows lagged levels of endogenous variables to become valid instruments. This method deals with serial correlation of the residuals in a rough way but has the disadvantages of over-differencing (see the estimate of $\rho$ in table 2) and of ignoring all information on level effects. In particular, variables that have only cross-sectional variation have no effect in this specification. Therefore, standard errors of coefficients (in parentheses) may be excessively high. 
Qualitatively, the results of the first-difference instrumental variables method tend to be consistent with the earlier results, although there are now more insignificant variables (third column in table 2). The coefficients of the fiscal variables and the current account ratio of developing countries remain significant. The Ricardian offset is slightly greater than before, while government investment (for a given level of the deficit) has a larger negative effect on private saving than does government consumption. About seven-tenths of external financing extended to developing countries displaces private saving. The dependency ratio retains its coefficient, implying that a 7 percentage point rise in the dependency ratio lowers the private saving by 1 percent of GDP, but it is now only significant at about the 10 percent level. Relative per capita GDP now has no explanatory power, no doubt because levels have been discarded and changeś in this variable occur only slowly. The $R^{2}$ statistics indicate that even in first differences, these regressions explain a relatively large proportion of the variation in the private saving ratio.

\section{Separate Panels of Industrial and Developing Countries}

It is interesting to consider the industrial- and developing-country panels separately, for at least three reasons. First, we were not able to use the same sources for the two groups. In particular, as mentioned, we calculated the fiscal variables for general government (the preferred concept) for industrial countries, but central government for developing countries (for which general government data are not readily available). Differences in data may be associated with different coefficients, for instance on the Ricardian offset. Second, behavioral differences may explain differences in coefficients (in addition to variation captured in separate country intercepts). For instance, financial development may change the sign and significance of interest rate effects, depending on whether savers or borrowers or both are insulated from market interest rates. Third, our focus on the nonlinearity of the relative income relationship suggests that dividing the sample into higher-income and lower-income countries may be useful.

The results for olS and a correction for serial correlation are given in table 3 for the two subgroups. Using the ols results, a test for equality of the coefficients across the two subgroups gives an $F$-statistic (with 11 and 890 degrees of freedom) of 7.12, well above the 1 percent critical value of 2.30 .

Therefore, it is of interest to look in more detail at differences between the two sets of estimates. From table 3, some notable differences can be seen in the signs and magnitude of coefficients on GDP growth, the real interest rate, wealth, the inflation rate, the percentage change in the terms of trade, and relative income. GDP growth is weakly associated with saving for industrial countries, but much more strongly and significantly so for developing countries, perhaps reflecting the greater importance of liquidity constraints and subsistence considerations. The real interest rate has a significant positive effect for industrial countries, but a negative, though insignificant, effect for developing countries, perhaps as a result of differences in financial liberalization. 
Table 3. Determinants of Private Saving: Panel Estimates with Separate Country Constant Terms

\begin{tabular}{|c|c|c|c|c|}
\hline \multirow[b]{2}{*}{ Variable } & \multicolumn{2}{|c|}{ Industrial countries } & \multicolumn{2}{|c|}{ Developing countries } \\
\hline & $\begin{array}{c}\text { Ordinary } \\
\text { least } \\
\text { squares }\end{array}$ & $\begin{array}{c}\text { Corrected } \\
\text { for serial } \\
\text { correlation }\end{array}$ & $\begin{array}{c}\text { Ordinary } \\
\text { least } \\
\text { squares }\end{array}$ & $\begin{array}{c}\text { Corrected } \\
\text { for serial } \\
\text { correlationt }\end{array}$ \\
\hline Government budget surplus/GDP & $\begin{array}{c}-0.57 \\
(9.4)\end{array}$ & $\begin{array}{r}-0.77 \\
(16.0)\end{array}$ & $\begin{array}{l}-0.63 \\
(9.4)\end{array}$ & $\begin{array}{c}-0.73 \\
(11.4)\end{array}$ \\
\hline Government current expenditure/GDP & $\begin{array}{r}-0.47 \\
(11.3)\end{array}$ & $\begin{array}{r}-0.49 \\
(10.5)\end{array}$ & $\begin{array}{l}0.0074 \\
(0.1)\end{array}$ & $\begin{array}{l}0.041 \\
(0.5)\end{array}$ \\
\hline Government investment/GDP & $\begin{array}{c}-0.60 \\
(5.7)\end{array}$ & $\begin{array}{c}-0.60 \\
(5.1)\end{array}$ & $\begin{array}{c}-0.23 \\
(2.7)\end{array}$ & $\begin{array}{c}-0.36 \\
(4.4)\end{array}$ \\
\hline GDP growth rate & $\begin{array}{l}-0.060 \\
(1.1)\end{array}$ & $\begin{array}{c}0.011 \\
(0.3)\end{array}$ & $\begin{array}{c}0.14 \\
(3.6)\end{array}$ & $\begin{array}{r}0.10 \\
(3.3)\end{array}$ \\
\hline Real interest rate & $\begin{array}{r}0.21 \\
(4.4)\end{array}$ & $\begin{array}{r}0.11 \\
(2.7)\end{array}$ & $\begin{array}{l}-0.021 \\
(0.6)\end{array}$ & $\begin{array}{l}-0.052 \\
(1.6)\end{array}$ \\
\hline Wealth/GDP & $\begin{array}{c}0.23 \\
(5.1)\end{array}$ & $\begin{array}{l}0.012 \\
(1.9)\end{array}$ & $\begin{array}{l}0.0072 \\
(1.1)\end{array}$ & $\begin{array}{l}-0.0067 \\
(0.8)\end{array}$ \\
\hline Inflation rate & $\begin{array}{c}0.18 \\
(4.6)\end{array}$ & $\begin{array}{l}0.083 \\
(2.2)\end{array}$ & $\begin{array}{l}-0.049 \\
(1.6)\end{array}$ & $\begin{array}{l}-0.064 \\
(2.1)\end{array}$ \\
\hline Percent change in the terms of trade & $\begin{array}{l}0.047 \\
(3.1)\end{array}$ & $\begin{array}{l}0.039 \\
(4.7)\end{array}$ & $\begin{array}{l}0.0067 \\
(0.6)\end{array}$ & $\begin{array}{l}0.0057 \\
(0.8)\end{array}$ \\
\hline Per capita GDP relative to U.S. & $\begin{array}{r}0.59 \\
(3.4)\end{array}$ & $\begin{array}{c}0.28 \\
(1.5)\end{array}$ & $\begin{array}{c}0.82 \\
(3.7)\end{array}$ & $\begin{array}{c}0.94 \\
(3.3)\end{array}$ \\
\hline Per capita GDP relative to U.S. squared & $\begin{array}{l}-0.0048 \\
(3.9)\end{array}$ & $\begin{array}{l}-0.0024 \\
(1.8)\end{array}$ & $\begin{array}{l}-0.0083 \\
(2.7)\end{array}$ & $\begin{array}{l}-0.0086 \\
(2.2)\end{array}$ \\
\hline Current account/GDP & & & $\begin{array}{r}0.46 \\
(11.2\rangle\end{array}$ & $\begin{array}{r}0.55 \\
(14.2)\end{array}$ \\
\hline Dependency ratio & $\begin{array}{c}-0.12 \\
(4.1)\end{array}$ & $\begin{array}{c}-0.18 \\
(3.6)\end{array}$ & $\begin{array}{c}-0.20 \\
(6.3)\end{array}$ & $\begin{array}{c}-0.18 \\
(4.4)\end{array}$ \\
\hline Fit statistics & & & & \\
\hline Adjusted $R^{2}$ & 0.77 & 0.72 & 0.84 & 0.71 \\
\hline Standard error of regression & 2.33 & 1.54 & 3.36 & 2.70 \\
\hline $\begin{array}{l}\text { Durbin-Watson } \\
\text { Panel autocorrelation coefficient, } \rho\end{array}$ & 0.64 & $\begin{array}{l}1.92 \\
0.75\end{array}$ & 1.04 & $\begin{array}{l}1.96 \\
0.59\end{array}$ \\
\hline Number of observations & 483 & 483 & 480 & 480 \\
\hline
\end{tabular}

Note: The dependent variable is the private saving/GDP ratio. Regressions are estimated using 197193 data for 21 industrial countries and 1982-93 data for 40 developing countries. Absolute $t$-ratios are in parentheses. See the appendix for countries, variable definitions, and data sources.

a. Dependent and independent variables are quasi-differenced to eliminate residual serial correlation, using the method of Bhargava, Franzini, and Narendranathan (1982). Country dummies are not reported. Source: Authors' calculations.

The coefficient for the wealth variable is (surprisingly) positive for industrial countries, but insignificant (and even negative) for developing countries. A similar contrast emerges for the inflation rate. The percentage change in the terms of trade is only significantly positive for industrial countries. This series is dominated by large changes in oil and other commodity prices, but developing countries include gainers as well as losers from these changes. Finally, because the industrial countries are all within about 50 percent of U.S. per capita income (near to the point at which the effect identified in the panel changes sign), this 
panel is unable to identify the two coefficients. In fact, including only the linear term gives a negative coefficient, as would be expected from the derivative of the quadratic function estimated in the combined panel, when evaluated in this interval.

The variables that are remarkably similar in effect in the two panels are the fiscal surplus, government investment, and dependency ratio. In particular, there is no evidence of difference in the Ricardian offset, despite the use of central government data for developing countries.

\section{Cross-Sectional Results}

Cross-sectional results are of interest for comparison with the first-difference specification and with earlier studies. Therefore, we estimated a simple oLs regression on the sample means for the variables that have significant crosssectional variation. The industrial country regressions involve 21 observations, one for each country, while the developing country and combined results involve 40 and 61 observations, respectively. The industrial country regressions use data averaged over the full 1971-93 period, while the other regressions use 1982-93 averages. The variables included are the government balance, real output growth, the dependency ratio, relative per capita GDP, and (in the case of the developing-country and combined estimates) the square of relative GDP.

The first column in table 4 reports the results for industrial countries from a restricted regression using these variables. A comparison with the results in table 3 indicates that the estimated coefficients tend to be greater in the crosssectional regression than in the time-series results. The cross-sectional analysis

\section{Table 4. Determinants of Private Saving: Cross-Sectional Estimates}

\begin{tabular}{lccc}
\hline Variable & $\begin{array}{c}\text { Industrial } \\
\text { countries }\end{array}$ & $\begin{array}{c}\text { Developing } \\
\text { countries }\end{array}$ & All countries \\
\hline Government budget surplus/GDP & -0.71 & -0.61 & -0.53 \\
& $(4.6)$ & $(2.0)$ & $(2.6)$ \\
GDP growth rate & 2.77 & 1.73 & 1.25 \\
& $(3.9)$ & $(3.1)$ & $(3.2)$ \\
Per capita GDP relative to U.S. & -0.06 & 0.72 & 0.16 \\
& $(1.7)$ & $(2.1)$ & $(1.3)$ \\
Per capita GDP relative to U.S. squared & & -0.014 & -0.0015 \\
& & $(2.1)$ & $(1.3)$ \\
Dependency ratio & -0.28 & -0.05 & -0.10 \\
& $(3.8)$ & $(1.0)$ & $(2.5)$ \\
Fit statistics & & & \\
Adjusted $R^{2}$ & 0.74 & 0.37 & 0.41 \\
Standard error of regression & 2.06 & 5.95 & 5.18 \\
Number of observations & 21 & 40 & 61 \\
\hline
\end{tabular}

Note: The dependent variable is the private saving/GDP ratio. Regressions are estimated using ols using 1971-93 averages for 21 industrial countries, 1982-93 averages for 40 developing countries, and 1982-93 averages for all 61 countries. Absolute $t$-ratios are in parentheses. See the appendix for countries, variable definitions, and data sources.

Source: Authors' calculations. 
attempts to explain the cross-country variation in saving on the basis of the independent variables, while the panel "explains" some of the variation through separate intercepts. The most dramatic difference is in the case of real growth, which has a coefficient of more than 2 in the cross-sectional regression. The time-series regressions measure the sensitivity of saving to changes over the economic cycle, while the cross-sectional regressions measure the impact of longterm differences in behavior. Thus the difference in the real growth coefficient may indicate that saving is more sensitive to long-term differences in output growth than to shorter-term movements in these variables. Alternatively, both saving and growth may be affected by some third variable that is not included and whose effect shows up in separate constant terms in the panel regressions. A somewhat larger coefficient is also estimated for the dependency ratio, although here the difference is less striking.

The second column in table 4 shows the results from running the same specification on the developing countries, except that the square of per capita relative GDP is included in the specification. As in the case of the industrial country regressions, the coefficient on growth is considerably higher in these crosssectional regressions than in the panel estimates reported earlier. The coefficients on the fiscal position and on the dependency ratio are actually lower in the cross-sectional regression than in the panel estimation, in contrast to both our own and others' results using industrial country data. Both the level and square of per capita relative GDP are significant. The coefficients are generally similar to those found in the panel estimation, although the peak value for saving implied by these point estimates occurs at around one-quarter of U.S. per capita GDP, which is lower than that found using the time-series estimates.

The last column in table 4 shows the results from the combined industrial and developing country data. As in the other cross-sectional regressions, the coefficient on growth is much higher than in the equivalent panel regression; however, the coefficients on the fiscal balance and dependency ratio are somewhat lower. The coefficients on the relative level of GDP and its squared value are also somewhat smaller than in the equivalent panel regression and are not very well determined. At around 60 percent of U.S. GDP, the implied peak level of saving is very similar to that found earlier.

Comparing the overall results from the cross-sectional regressions with those found using panel estimation provides a number of interesting insights. First, the two approaches provide reasonably similar estimated coefficients (for those variables that are included in both regressions), except in the case of output growth. This contrasts with results using only industrial country data, where several authors have pointed to the very different coefficients, in particular for demographic variables, produced by the two estimation techniques (see, for example, Bosworth 1993). Second, the results confirm the quadratic relationship between saving and per capita income. Finally, the strong relationship between saving and growth in the cross-sectional results may well imply a joint response to a third variable that affects the long-run values of each in the same direction. 
Changes in the rate of growth in output over the cycle, by contrast, appear from the panel estimates to have a much smaller impact on the saving rate.

\section{CONCLUDING REMARKS}

Several conclusions emerge clearly from the regressions, despite some heterogeneity in the results. First, there seems to be a substantial offset of changes in the government fiscal position from private saving, averaging 75 percent, depending on whether those changes are due to changes in government spending or in taxes. Although this offset is large, it is considerably below unity, implying that changes in the government's fiscal position can have a significant impact on national saving, especially if they result from reductions in spending.

The estimates for both country groups show that demographic effects are an important determinant of private saving rates. However, the size of the effect of the dependency ratio on private saving is somewhat lower than in most previous studies that found a significant saving impact from demographic variables. The coefficients on the demographic variables are similar across different estimation techniques.

The results identify a number of channels through which growth influences saving. A direct positive association between GDP growth and private saving emerges from most of the specifications, especially for developing countries, although it is unclear whether there is a causal effect in either direction or a joint response to a third factor. A suggestive result concerns the level of per capita income (relative to the United States) and saving. For developing countries, the analysis finds a generally significant positive effect of the level, but a negative effect of the squared level, of per capita income. This result implies that beyond a certain point higher income has a negative effect on the private saving rate. The combined panel and the cross sections are consistent with this implication.

The real interest rate has a positive, and significant, coefficient for industrial countries, but the results are not very robust. Measurement problems related to the choice of the appropriate interest rate and measure of inflation may, in particular, affect the results for developing countries, for which the coefficient is negative, but insignificant. Different levels of financial development may explain the results, but it may also be the case that financial reforms changed the relationship during the sample period.

Changes in the terms of trade have a significantly positive effect on saving for industrial countries (for which a longer sample was available), but not for developing countries or the combined panel. The terms of trade in many countries deteriorated due to the oil price shocks of 1973 and 1979, and the deterioration had large effects in reducing their saving rates. Conversely, the terms of trade improved in oil-exporting countries and increased their saving, at least for a time. However, the effect is transitory, and because terms-of-trade changes balance out at the world level, there is no presumption that this variable will durably affect world saving. An additional external factor that negatively affects 
private saving in developing countries is the level of foreign saving. As in the case of the government fiscal position, however, the offset, though large, is only partial, implying that foreign saving raises domestic investment.

\section{APPENDIX. DATA SOURCES \\ Industrial Country Data}

The 21 industrial countries for which data were available are the following: Australia, Austria, Belgium, Canada, Denmark, Finland, France, Germany, Greece, Ireland, Italy, Japan, Netherlands, New Zealand, Norway, Portugal, Spain, Sweden, Switzerland, United Kingdom, and United States.

Most of the data came from the International Monetary Fund's World Economic Outlook (WEO) Database, supplemented in some cases by Organisation for Economic Co-operation and Development (OECD) sources (mainly the OECD Analytical Database). Specifically, OECD values were used for the private saving rate in Portugal and for some general government fiscal surplus and investment series. The dependency ratio data came from United Nations (1992). In some cases, the central government fiscal surplus was used to infer historical general government values. General government current expenditures were calculated as total general government expenditures less general government investment. The real interest rate was calculated as the short-term rate minus current inflation. Private wealth was calculated as the sum of the beginning-of-period capital stock (from the OECD Analytic Database where available; otherwise from cumulated investment), government debt, and net foreign assets. Some of the historical values for net foreign assets were calculated by cumulating current account values backward from the earliest available figures.

\section{Developing Country Data}

The data source for developing countries was the wEO Database, except for the interest rate, for which data from the International Monetary Fund's International Financial Statistics were used for some countries to supplement the WEO Database (specifically, China, Paraguay, and Uruguay).

The regressions include the following 40 countries (dictated by data availability): Algeria, Bangladesh, Benin, Burkina Faso, Burundi, Cameroon, Central African Republic, Chile, China, Colombia, Costa Rica, Cyprus, Ecuador, Egypt, El Salvador, Gabon, The Gambia, Honduras, India, Indonesia, Islamic Republic of Iran, Jamaica, Kenya, Republic of Korea, Lesotho, Oman, Malaysia, Mali, Malta, Mauritius, Morocco, Nepal, Nigeria, Panama, Paraguay, Rwanda, Turkey, Uruguay, Venezuela, and Zimbabwe.

\section{REFERENCES}

The word "processed" describes informally reproduced works that may not be commonly available through library systems. 
Aghevli, Bijan, James Boughton, Peter Montiel, Delano Villanueva, and Geoffrey Woglom. 1990. The Role of National Saving in the World Economy. Occasional Paper 67. Washington, D.C.: International Monetary Fund.

Anderson, T. W., and Cheng Hsiao. 1982. "Formulation and Estimation of Dynamic Models Using Panel Data." Journal of Econometrics 18(1):47-82.

Bayoumi, Tamim. 1993. "Financial Deregulation and Household Saving." The Economic Journal 103(November):1432-43.

Bernheim, B. D. 1987. "Ricardian Equivalence: An Evaluation of Theory and Evidence." In NBER Macroeconomics Annual 1987. Cambridge, Mass.: MrT Press.

Bernheim, B. D., and J. B. Shoven. 1988. "Pension Funding and Saving." In Zvi Bodie, J. B. Shoven, and D. A. Wise, eds., Pensions in the U.S. Economy. Chicago: University of Chicago Press.

Bhargava, A., L. Franzini, and W. Narendranathan. 1982. "Serial Correlation and the Fixed-Effects Model." Review of Economic Studies 49(October):533-49.

Blades, D. W., and Peter Sturm. 1982. "The Concept and Measurement of Savings: The United States and Other Industrialized Countries." In Saving and Government Policy. Proceedings of a conference sponsored by the Federal Reserve Bank of Boston, Melvin Village, N. H., October. Boston: Federal Reserve Bank of Boston.

Bosworth, B. P. 1993. Saving and Investment in a Global Economy. Washington, D.C.: Brookings Institution.

Campbell, J. Y., and N. G. Mankiw. 1989. “Consumption, Income, and Interest Rates: Reinterpreting the Time-Series Evidence." NBER Working Paper 2924. National Bureau of Economic Research, Cambridge, Mass. Processed.

Carroll, C. D., and Lawrence Summers. 1991. "Consumption Growth Parallels Income Growth: Some New Evidence.” In B. D. Bernheim and John Shoven, eds., National Saving and Economic Performance. Chicago: University of Chicago Press.

Carroll, C. D., and David Weil. 1994. "Saving and Growth: A Reinterpretation." Carnegie-Rochester Conference on Public Policy 40(June):133-92.

Corbo, Vittorio, and Klaus Schmidt-Hebbel. 1991. "Public Policies and Saving in Developing Countries." Journal of Development Economics 36(July):89-115.

Deaton, A. S. 1992. Understanding Consumption. Oxford: Clarendon Press.

De Gregorio, José, and Pablo Guidotti. 1994. "Financial Development and Economic Growth.” Research Department, International Monetary Fund, Washington, D.C. Processed.

Edwards, Sebastian. 1996. "Why Are Saving Rates So Different across Countries? An International Comparative Analysis." NBER Working Paper 5097. National Bureau of Economic Research, Cambridge, Mass. Processed.

Elmeskov, Jorgen, Jeffrey Shafer, and Warren Tease. 1991. "Saving Trends and Measurement Issues." Economics and Statistics Department Working Paper 105. Organisation for Economic Co-operation and Development, Paris. Processed.

Flavin, Marjorie A. 1981. "The Adjustment of Consumption to Changing Expectations about Future Income." Journal of Political Economy 89(5):1020-37.

Fry, M. J. 1978. "Money and Capital or Financial Deepening in Economic Development?" Journal of Money, Credit, and Banking 10(November):464-75.

-1980. "Saving, Investment, Growth, and the Cost of Financial Repression." World Development 8(4):317-27. 
Giovannini, Alberto. 1985. "Saving and the Real Interest Rate in LDCs." Journal of Development Economics 18(August):197-218.

Graham, J. W. 1987. “International Differences in Saving Rates and the Life-Cycle Hypothesis.” European Economic Review 31(December):1509-29.

Haque, N. U., and Peter Montiel. 1989. "Consumption in Developing Countries: Tests for Liquidity Constraints and Finite Horizons." The Review of Economics and Statistics 71(3):408-15.

Hayashi, Fumio. 1985. "The Permanent Income Hypothesis and Consumption Durability: Analysis Based on Japanese Data." Quarterly Journal of Economics 100(November):1083-113.

Horioka, C. Y. 1993. “Saving in Japan." In Arnold Heertje, ed., World Savings: An International Survey, pp. 238-78. Oxford: Blackwell Publishers.

Jappelli, Tullio, and Marco Pagano. 1989. "Consumption and Capital Market Imperfections: An International Comparison." The American Economic Review 79(5):1088105.

Kennickell, Arthur. 1990. Demographics and Household Savings. Finance and Economics Discussion Series 123(May). Washington, D.C.: Federal Reserve Board, Division of Research and Statistics.

Kessler, Denis, Sergio Perelman, and Pierre Pestieau. 1993. "Savings Behavior in 17 OECD Countries." Review of Income and Wealth Series 39(1):37-49.

Koskela, Erkki, and Matti Viren. 1989. "International Differences in Saving Rates and the Life-Cycle Hypothesis: A Comment." European Economic Review 33(September):1489-98.

Leff, N. H. 1969. "Dependency Rates and Savings Rates." American Economic Review 59(5):886-96.

Lehmussaari, O. P. 1990. "Deregulation and Consumption: Saving Dynamics in the Nordic Countries." IMF Staff Papers 37(March):71-93.

Lipsey, R. E., and I. B. Kravis. 1987. Saving and Economic Growth: Is the United States Really Falling Behind? Report 901. New York: American Council of Life Insurance and the Conference Board.

Masson, Paul R., and R. W. Tryon. 1990. "Macroeconomic Effects of Projected Population Aging in Industrial Countries." IMF Staff Papers 37(September):453-85.

McKinnon, R. I. 1973. Money and Capital in Economic Development. Washington, D.C.: Brookings Institution.

Modigliani, Franco. 1966. "The Life-Cycle Hypothesis of Saving, the Demand for Wealth, and the Supply of Capital." Social Research 33(summer):160-217.

1970. "The Life-Cycle Hypothesis of Saving and Intercountry Differences in the Saving Ratio." In W. A. Eltis, M. F. Scott, and J. N. Wolfe, eds., Induction, Growth, and Trade, pp. 197-225. Oxford: Clarendon Press.

Modigliani, Franco, and Albert Ando. 1957. "Tests of the Life-Cycle Hypothesis of Savings: Comments and Suggestions." Bulletin of the Oxford Institute of Statistics May:99-124.

Modigliani, Franco, and Richard Brumberg. 1954. "Utility Analysis and the Consumption Function: An Interpretation of Cross-Section Data." In E. E. Kurihara, ed., PostKeynesian Economics, pp. 388-436. New Brunswick, N.J.: Rutgers University Press. 
Modigliani, Franco, and Arlie Sterling. 1983. "Determinants of Private Saving with Special Reference to the Role of Social Security: Cross-Country Tests." In Franco Modigliani and Richard Hemming, eds., The Determinants of National Saving and Wealth. New York: St. Martin's Press.

Obstfeld, Maurice. 1982. "Aggregate Spending and the Terms of Trade: Is There a Laursen-Metzler Effect?" The Quarterly Journal of Economics 97(1):251-70.

Ogaki, Masao, Jonathan Ostry, and C. M. Reinhart. 1995. "Saving Behavior in Lowand Middle-Income Developing Countries: A Comparison." Working Paper WP/95/ 3. International Monetary Fund, Washington, D.C. Processed.

Ostry, J. D., and Joaquim Levy. 1995. "Household Saving in France: Stochastic Income and Financial Deregulation." IMF Staff Papers 42(June):375-97.

Ostry, J. D., and C. M. Reinhart. 1992. "Private Saving and Terms-of-Trade Shocks." IMF Staff Papers 39(September):495-517.

Schmidt-Hebbel, Klaus, S. B. Webb, and Giancarlo Corsetti. 1992. "Household Saving in Developing Countries: First Cross-Country Evidence." The World Bank Economic Review 6(3):529-47.

Seater, John. 1993. “Ricardian Equivalence." Journal of Economic Literature 31(March):142-90.

Shaw, E. S. 1973. Financial Deepening in Economic Development. New York: Oxford University Press.

Svensson, L. E. O., and Assaf Razin. 1983. "The Terms of Trade and the Current Account: The Harberger-Laursen-Metzler Effect." Journal of Political Economy 91(1):97125.

Tobin, James. 1967. “Life-Cycle Saving and Balanced Growth.” In William Fellner, ed., Ten Economic Studies in the Tradition of Irving Fisher, pp. 231-56. New York: John Wiley and Sons.

United Nations. 1992. World Population Prospects, 1992 rev. New York.

Weil, David N. 1994. “The Saving of the Elderly in Micro and Macro Data." The Quarterly Journal of Economics 109(February):55-81. 